\title{
Ampullary Adenocarcinoma in Neurofibromatosis Type 1. Case Report and Literature Review
}

\author{
Renato Costi, M.D., Pietro Caruana, M.D., Leopoldo Sarli, M.D., Vincenzo Violi, M.D., \\ Luigi Roncoroni, M.D., Cesare Bordi, M.D. \\ Department of Surgery (RC, LS, VV, LR), Institute of General Surgery, and Department of Pathology (PC, \\ CB), Section of Anatomic Pathology, University of Parma School of Medicine, Parma, Italy
}

\begin{abstract}
Periampullary tumors in patients affected by Neurofibromatosis Type 1 (NF-1) are usually carcinoids or stromal tumors and, rarely, adenocarcinomas. We report a case of an adenocarcinoma of the ampulla of Vater in a 54-year-old woman with NF-1 admitted to the hospital with jaundice and undergoing pancreato-duodenectomy. Histologically, the resected specimen showed an adenocarcinoma of the ampulla as being a part of a complex atypical epithelial proliferation extended from the papilla to the mucosa of the duodenum and distal choledochus, islet-cell adenomatosis of the pancreas and multiple gastric, duodenal, jejunal stromal tumors. The ampullary and periampullary adenocarcinomas in NF-1 patients have peculiar features, suggesting a widespread predisposition to cancer development in periampullary tissues and requiring widely demolitive surgery. Moreover, they occur at a younger age than those occurring in non-NF-1 patients, may be associated with additional periampullary epithelial tumors, are often operable and may present long survival.
\end{abstract}

KEY WORDS: Ampulla, Neurofibromatosis Type 1, Pancreato-duodenectomy, Periampullary adenocarcinoma, Von Recklinghausen's disease.

Mod Pathol 2001;14(11):1169-1174

Neurofibromatosis Type 1 (NF-1) is an autosomally inherited neurofibromatosis occurring with an incidence of about 1 per 3000 births, equally involving males and females. The genetic basis of the disease is a mutation located on chromosome $17 q 11.2$ (1). Although recently a wide variety of genetic mutations has been described (2-4), no frequently recurring mutation has been identified,

Copyright (C) 2001 by The United States and Canadian Academy of Pathology, Inc.

VOL. 14, NO. 11, P. 1169, 2001 Printed in the U.S.A

Date of acceptance: July 12, 2001.

Address reprint requests to: Cesare Bordi, M.D., Istituto di Anatomia ed Istologia Patologica, Via Gramsci 14, 43100 Parma, Italia; e-mail: cesare.bordi@unipr.it; fax: 39-0521-292710. and diagnosis is still based on established clinical criteria (5). The "classic triad" of symptoms is: cafèau-lait spots (brown skin pigmentation), cutaneous neurofibromas, and neoplasms of the peripheral or central nervous system.

Malignancies are found in 3 to $15 \%$ of patients. Gastrointestinal (GI) involvement is present in about one-fourth of the cases (6) and usually occurs in three principal forms: hyperplasia of submucosal or myenteric nerve plexuses, GI stromal tumors (GISTs), and periampullary carcinoids, sometimes associated with pheochromocytoma (7). The association with duodenal gangliocytic paraganglioma has also been described (7). The clinical onset of these lesions, which for the most part remain asymptomatic, is generally characterized by abdominal pain, obstruction or bleeding.

This report illustrates a case of ampullary adenocarcinoma with complex pathologic features and associations observed in a patient affected by NF-1.

\section{CASE REPORT}

A 54-year-old white woman affected by NF-1 presented with a 2-week history of jaundice. Her family history included a 30-year-old son affected by NF-1, treated for IDDM at the age of 10 years, and who underwent brain surgery for nonspecified brain tumor at age 19. Laboratory data showed hyperbilirubinemia (direct bilirubin: $14.2 \mathrm{mg} / \mathrm{dL}$ ). Ultrasounds, ERCP and CT scan showed a dilated common bile duct $(1.7 \mathrm{~cm})$ presenting hyperdensity and irregular thickening of the wall in the distal tract, microlithiasis of the gallbladder, adipose involution of the pancreas and abnormal thickening of the greater curvature of the stomach. Surgical examination revealed an ampullary tumor about $1 \mathrm{~cm}$ in diameter. A Whipple operation was performed, and 15 days later the patient was discharged.

A detailed, systematic pathologic analysis based on serial sections of the whole surgical specimen was performed. This study revealed an atypical epithelial proliferation that uninterruptedly extended 
from the papilla and the surrounding duodenal mucosa to the mucosa of the dilated choledochus up to $3 \mathrm{~mm}$ from the resection border. The histologic features of this diffuse proliferation showed considerable variations in contiguous areas though with merging transitions from one pattern to another. The tumor in the papilla and adjacent duodenal mucosa was a tubular adenoma with occasional papillary projections, mild dysplasia, and no evidence for stromal invasion (Fig. 1). In the ampullary region the neoplastic proliferation became clearly atypical with the appearance of papillary adenocarcinoma and extensive infiltration of the surrounding pancreatic tissue reaching a transverse diameter of $0.9 \mathrm{~cm}$. The infiltrating tumor showed pronounced anaplasia including giant cell features (Fig. 2). The remaining portion of the choledochus showed intraductal papillary neoplasia with variable degree of dysplasia and serial foci of intraductal papillary carcinoma (Fig. 3). The remaining part of the pancreas showed frequent duct dilatations with findings of papillary dysplasia, focal periductal and acinar fibrosis, nesidioblastosis, and microadenomatous changes of islet tissue with nodules ranging up to $2 \mathrm{~mm}$ in size and showing extensive ribbon histologic pattern (Fig. 4). Immunohistochemically, these structures were mostly composed of pancreatic-polypeptide-producing cells. The surgical borders were free of tumor invasion. All lymph nodes examined (five) were tumor free.

An additional finding in the case was the occurrence of multiple GISTs of the wall of the stomach, duodenum and jejunum, ranging in diameter from 0.5 to $1.8 \mathrm{~cm}$. By immunohistochemistry they consistently expressed CD 34 but were unreactive to either S100 or smooth muscle actin.

Abdominal ultrasound examination (performed 6 and 18 months after surgery) and the abdominal CT scan (performed 12 and 24 months after surgery) showed no signs of distant local recurrence. Three years after discharge the patient is doing well.

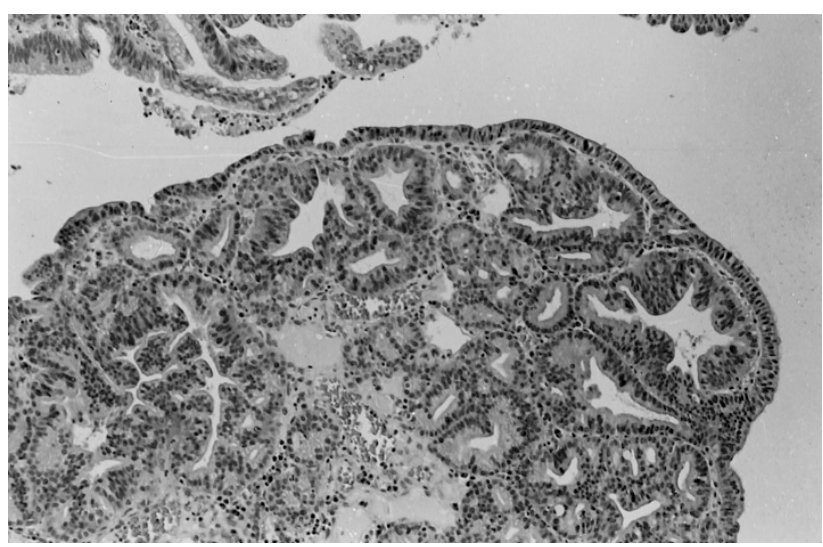

FIGURE 1. Tubular adenoma with mild dysplasia abutting on the surface of the mucosa of the Vater's papilla.

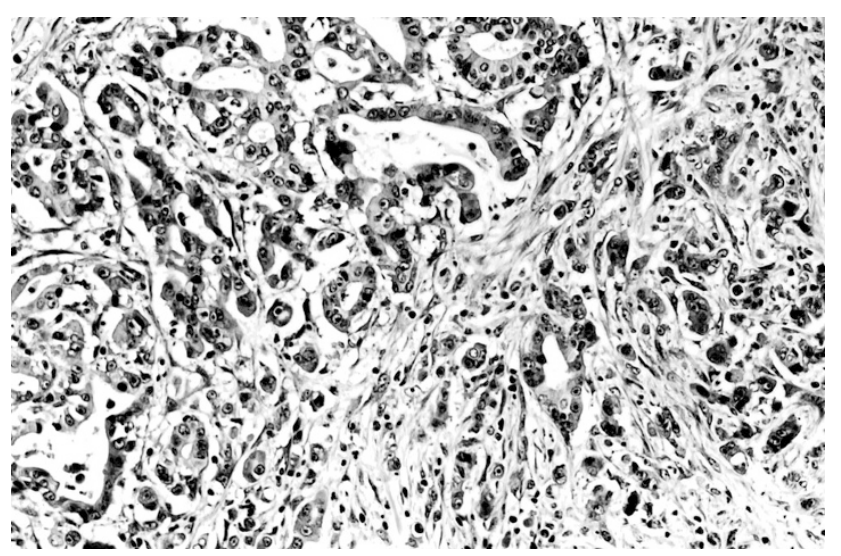

FIGURE 2. Ductal adenocarcinoma of the ampulla showing poorly differentiated features.

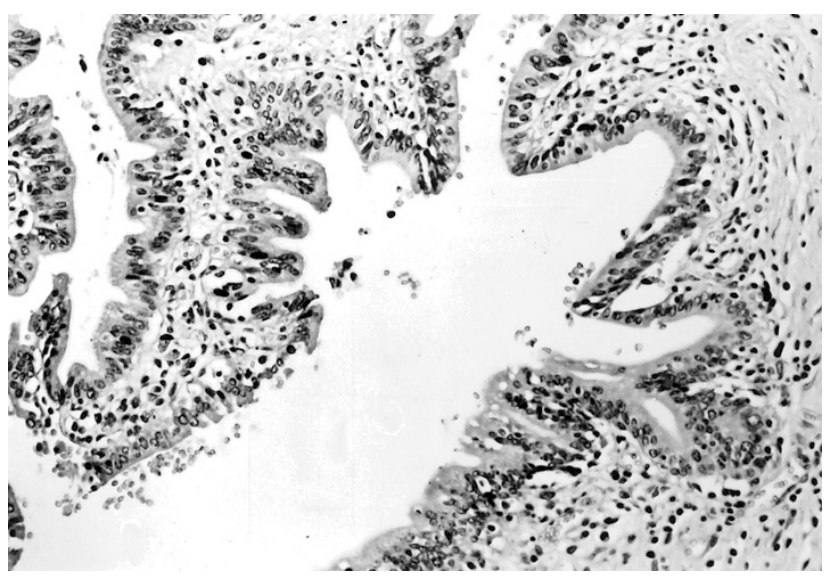

FIGURE 3. Epithelium lining the intrapancreatic segment of the choledochus with dysplasia evolving into intraductal adenocarcinoma with papillary pattern.

\section{DISCUSSION}

The case here described presents, in addition to the unusual association of NF-1 with a rare adenocarcinoma of the ampulla of Vater, also concomitant alterations of periampullary epithelial tissues and multiple GISTs at gastric, duodenal and jejunal level.

Although they are rarer than stromal and carcinoid tumors, GI adenocarcinomas in NF-1 patients are reported in literature, affecting the esophagus (8), stomach (9), duodenum (10), small bowel (11), colon (12), gallbladder (13), biliary tract (14), liver (15), and pancreas (16). In the most extensive review (17) of tumors of the periampullary region (duodenum, ampulla of Vater, distal biliary tract, gallbladder, head of pancreas) in NF-1 patients up to now available in the literature, three cases of adenocarcinomas were reported (one of the duodenum, one of the ampulla, and one of the pancreas), in addition to 19 cases of stromal tumors and 15 cases of carcinoids.

A survey of the English literature prompted us to collect 12 NF-1 patients affected by 15 ampullary 


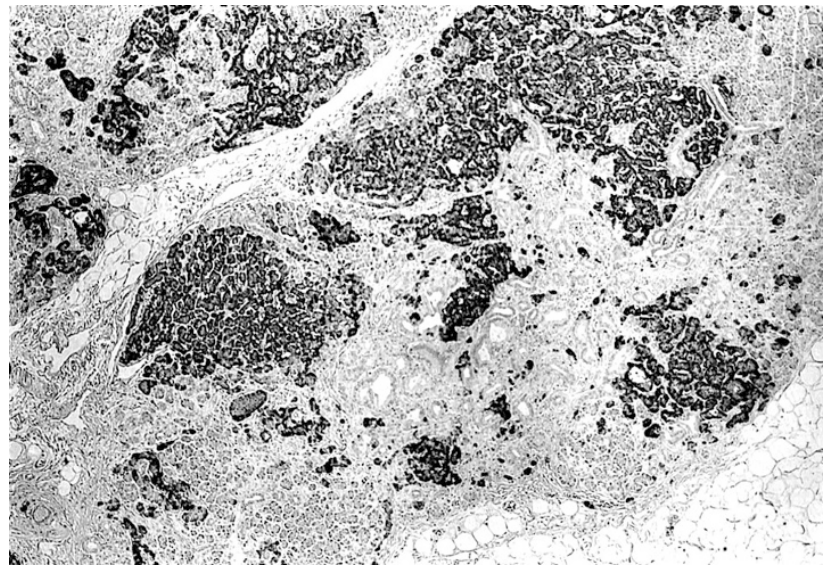

FIGURE 4. Islet cell microadenomatosis in the pancreatic tissue surrounding the bile duct as depicted by chromogranin A immunostaining. The majority of cells in these lesions were immunoreactive for pancreatic polypeptide.

and periampullary epithelial tumors (exclusive of carcinoids) (Table 1). These tumors were located in the ampulla of Vater in five cases $(13,18-20$, and the present one), in the head of the pancreas in four cases $(16,21-23)$, in the duodenum in four cases $(10,19,22,24)$, in the bile duct in one case (23), and in the gallbladder in one case (13). From this analysis it emerges that the association of epithelial cancers with NF-1 is equally distributed between the sexes (seven males, five females, and two of unknown sex), in accordance with the general distribution of NF-1. The most frequent symptom of onset is jaundice, present in 10 cases. The age of onset of periampullary noncarcinoid epithelial tumors in NF-1 patients is low: only four patients are older than 50 years old, and only two are older than 60 , with an average of 47.1 (first tumor) (range 27 to 73). This type of age distribution differs from that observed for sporadic epithelial tumors of this region not associated with NF-1, which usually occur after 60 years of age (25).

The case we reported differs from the previously reported cases in the complex appearance of histopathologic findings of the ampullary and periampullary region and the association with GISTs. The adenocarcinoma was part of a diffuse neoplastic growth of the whole segment from the papilla to the choledochus with varying histologic patterns at different locations: tubular adenoma of the papilla (Fig. 1), poorly differentiated infiltrating carcinoma of the ampulla (Fig. 2), and intraductal papillary tumor of the distal choledochus (Fig. 3). Moreover, islet cell microadenomatosis of the pancreas was also present (Fig. 4). The association of an adenocarcinoma of the papilla with dysplasia of the duodenum and of the terminal choledochus (24) and an adenocarcinoma of the pancreas with focal atypical proliferation of the pancreatic ducts (16) have already been described.
In three (25\%) of the NF-1 patients affected with periampullary noncarcinoid epithelial tumors shown in Table 1, the occurrence of a second tumor of epithelial origin is described at the periampullary site (synchronous in one case and 6 years and 13 years after surgery, respectively, in the other two) $(13,19,22)$. This frequency could be an underestimation if it is considered that three of the remaining nine patients in whom a single neoplasm was described died during follow-up because of tumor or surgery, and in the remaining six cases follow-up was not reported or was inadequate (less than 1 year). Such a high rate of occurrence of a second periampullary carcinoma in patients affected by NF-1 and periampullary carcinoma is unlikely to happen by chance. A more probable explanation is the predisposition of the periampullary region of these patients to develop multiple epithelial tumors, or, as this observation of ours would seem to suggest, the predisposition of the site to develop a single diffuse neoplastic growth of the epithelial tissues of the area with differing grades of progression of the disease at the different locations. This feature may be misdiagnosed as the contemporaneous presence of two different neoplasms, as possibly happened in the case of two synchronous adenocarcinomas of the pancreas and duodenum (22). Also for the two cases in the literature $(13,19)$ in which two periampullary neoplasms showed up at a distance after a long disease-free interval, the second adenocarcinoma may have developed starting from a periampullary epithelial dysplasia already present but not removed at the time of initial surgery.

In this light, in the case here observed the contemporaneous presence of an insular adenomatosis of the pancreatic parenchyma seemed to us to be of particular interest. This finding lends further support to the hypothesis of a more complex predisposition of several types of tissues in this region, including duodenum, papilla, ampulla and pancreas, to tumor development.

Another aspect peculiar to our finding is the presence of GISTs. The association between NF-1 and GISTs is well recognized. GISTs are the GI tumors most frequently associated with NF-1 (7) and they are reported to present neural differentiation (previously diagnosed as neurofibromas or schwannomas) in some cases (26), or else muscular (more rarely) (27), or no differentiation, as in the present case. The increased occurrence of GI carcinoids, particularly of the ampulla, was also recognized some time ago in NF-1 patients (28-31) and more recently confirmed $(17,32)$. It is, however, rare to find in NF-1 patients the contemporaneous presence of GISTs and adenocarcinoma of the ampulla that we observed in this case. The frequent association of GISTs and NF-1, and the frequency with 


\begin{tabular}{|c|c|c|c|c|c|c|c|}
\hline No. & Patient & Location & Histology & Notes & Surgery & Outcome & Source \\
\hline 1 & $\begin{array}{l}\text { M, } 40 \text {, } \\
\text { steatorrhea }\end{array}$ & Duodenum & Adenocarcinoma (well-diff) & Thalassemia minor & Local excision & $\begin{array}{l}\text { Alive } \\
\qquad \text { (6 months) }\end{array}$ & 10 \\
\hline 2 & M, 73 & Pancreas & Adenocarcinoma & $\begin{array}{l}\text { Solitary } \\
\text { neurofibroma of } \\
\text { the mediastinum } \\
\text { ( } 2 \text { years before) }\end{array}$ & Unknown & Unknown & 21 \\
\hline 3 & $\begin{array}{l}\mathrm{F}, 27, \\
\quad \text { recurrent } \\
\text { pancreatitis }\end{array}$ & Pancreas & Adenocarcinoma (mod-diff) & $\begin{array}{l}\text { Node metastasis, } \\
\text { gallbladder and } \\
\text { common bile duct } \\
\text { stones }\end{array}$ & $\begin{array}{l}\text { Surgical exploration } \\
\text { (twice), } \\
\text { gastroenterostomy }\end{array}$ & $\begin{array}{l}\text { Dead } \\
\qquad(9 \text { months })\end{array}$ & 16 \\
\hline 4 & $\begin{array}{l}\mathrm{F}, 29, \\
\text { jaundice, } \\
\text { weight loss }\end{array}$ & Duodenum & $\begin{array}{l}\text { Adenocarcinoma (well-diff) } \\
\text { infiltrating deep the } \\
\text { muscolar layer, duodenal } \\
\text { dysplasia, dysplasia of } \\
\text { terminal common bile } \\
\text { duct }\end{array}$ & Node metastasis & $\begin{array}{l}\text { Pancreato- } \\
\text { duodenectomy }\end{array}$ & $\begin{array}{l}\text { Dead } \\
\qquad(4 \text { months })\end{array}$ & 24 \\
\hline 5 & 58 & Bile duct & Carcinoma & $\begin{array}{c}\text { Astrocitoma ( } 32 \\
\text { years before) }\end{array}$ & Unknown & Unknown & 25 \\
\hline 6 & 38 & Pancreas & Adenocarcinoma & $\begin{array}{l}\text { Pheochromocytoma } \\
\text { (same year) }\end{array}$ & Unknown & Unknown & 25 \\
\hline 7 & $\begin{array}{l}\text { M, } 65, \\
\text { jaundice }\end{array}$ & Ampulla & $\begin{array}{l}\text { Papillary adenocarcinoma } \\
\text { (well-diff), duodenal } \\
\text { infiltration }\end{array}$ & $\begin{array}{c}\text { Tumor free nodes, } \\
\text { paraampullary } \\
\text { duodenal cyst }\end{array}$ & $\begin{array}{l}\text { Pancreato- } \\
\text { duodenectomy }\end{array}$ & Unknown & 20 \\
\hline \multirow[t]{2}{*}{8} & \multirow[t]{2}{*}{$\begin{array}{l}\text { M, } 47, \\
\text { jaundice, } \\
\text { anemia }\end{array}$} & Duodenum & Adenocarcinoma (well-diff) & \multirow[t]{2}{*}{$\begin{array}{l}\text { Liver metastasis, } \\
\text { bile duct } \\
\text { bifurcation } \\
\text { stricture }\end{array}$} & \multirow[t]{2}{*}{ None } & \multirow[t]{2}{*}{$\begin{array}{c}\text { Dead (day } \\
4 \text {-liver } \\
\text { failure) }\end{array}$} & \multirow[t]{2}{*}{22} \\
\hline & & $\begin{array}{l}\text { Pancreas } \\
\text { (synchronous) }\end{array}$ & Adenocarcinoma (well-diff) & & & & \\
\hline \multirow[t]{2}{*}{9} & \multirow[t]{2}{*}{$\begin{array}{l}\mathrm{F}, 57, \\
\text { jaundice }\end{array}$} & Duodenum & Adenocarcinoma & \multirow[t]{2}{*}{$\begin{array}{l}\text { Duodenal } \\
\text { neurofibromatosis }\end{array}$} & Local excision & \multirow[t]{2}{*}{$\begin{array}{l}\text { Alive } \\
\qquad(10 \text { years })\end{array}$} & \multirow[t]{2}{*}{19} \\
\hline & & $\begin{array}{l}\text { Ampulla } \\
\text { (6 years } \\
\text { later) }\end{array}$ & Adenocarcinoma & & Local excision & & \\
\hline 10 & $\begin{array}{l}\text { M, } 31, \\
\text { jaundice, } \\
\text { weight loss }\end{array}$ & Ampulla & Adenocarcinoma (well-diff) & Tumor free nodes & $\begin{array}{l}\text { Pancreato- } \\
\text { duodenectomy }\end{array}$ & Unknown & 18 \\
\hline \multirow[t]{2}{*}{11} & \multirow[t]{2}{*}{$\begin{array}{l}\text { M, } 47, \\
\text { jaundice }\end{array}$} & Ampulla & Adenocarcinoma (mod-diff) & $\begin{array}{l}\text { Neurofibromata } \\
\text { involving adjacent } \\
\text { lymph nodes }\end{array}$ & $\begin{array}{l}\text { Pancreato- } \\
\text { duodenectomy }\end{array}$ & \multirow[t]{2}{*}{$\begin{array}{l}\text { Alive } \\
\qquad \text { (22 years) }\end{array}$} & \multirow[t]{2}{*}{13} \\
\hline & & $\begin{array}{l}\text { Gallbladder } \\
\text { (13 years } \\
\text { later) }\end{array}$ & $\begin{array}{l}\text { Adenocarcinoma invading } \\
\text { submucosa }\end{array}$ & $\begin{array}{l}\text { Tumor free nodes, } \\
\text { acute } \\
\text { cholecystitis, } \\
\text { gallbladder stones }\end{array}$ & Cholecystectomy & & \\
\hline 12 & $\begin{array}{l}\mathrm{F}, 54, \\
\text { jaundice }\end{array}$ & Ampulla & $\begin{array}{l}\text { Adenocarcinoma (poor- } \\
\text { diff), duodenal dysplasia, } \\
\text { dysplasia of terminal } \\
\text { CBD }\end{array}$ & $\begin{array}{l}\text { Tumor free nodes, } \\
\text { islet-cell } \\
\text { adenomatosis of } \\
\text { the pancreas, } \\
\text { multiple gastric, } \\
\text { duodenal, jejunal } \\
\text { stromal tumors, } \\
\text { gallbladder stones }\end{array}$ & $\begin{array}{l}\text { Pancreato- } \\
\text { duodenectomy }\end{array}$ & $\begin{array}{l}\text { Alive } \\
\text { (3 years) }\end{array}$ & $\begin{array}{r}\text { Present } \\
\text { case }\end{array}$ \\
\hline
\end{tabular}

Well-diff, well differentiated; mod-diff, moderately differentiated; poor-diff, poorly differentiated.

which NF-1 patients already affected by one tumor develop a second one ( $46 \%$ versus $4 \%$ in the general population) (23), do not seem to support a specific relationship between the development of both GISTs and the adenocarcinoma of the ampulla, but rather a chance association.

Various authors, however, have suggested the embryologic basis for all these correlations. Arnesjo (29), who first reported a case of a multiple duodenal, jejunal and ileal neurofibromatosis in a NF-1 patient, described the presence at histopathologic examination of a mixed tumor (neurofibroma in the deeper tissues and carcinoid in the surface layers), and hypothesized the presence of a multipotential neuroectodermal potentially evolving into both endocrine and neural cell lines. The presence of an endodermal-neuroectodermal complex composed of several cell lines, including epithelial cells, ganglion cells and Schwann cells in the pancreas, small bowel and appendix was described by Von Campenhout, quoted by Klein (17). Perrone (33) suggested that neurofibromas, paragangliomas and carcinoids may derive from this endodermal-neuroectodermal complex. Interestingly enough, in fact, in the small bowel the complex is concentrated near the papilla of Vater, the location with the highest frequency of malignancy 
TABLE 2. Surgical Treatment and Outcome of Ampullary/Periampullary Adenocarcinomas Associated with Neurofibromatosis Type 1

\begin{tabular}{llll}
\hline \multicolumn{1}{c}{ Surgery } & \multicolumn{1}{c}{ Type of operation } & No. & \multicolumn{1}{c}{ Outcome } \\
\hline Curative (potentially) & Pancreato-duodenectomy & 5 & $\begin{array}{l}\text { 1 dead (4 months-lymph node metastasis at histology) } \\
4 \text { alive (FUNR, FUNR, 22 years, 3 years) } \\
\end{array}$ \\
& Resection, local excision & & Alive (6 months, 10 years, FUNR) \\
& Cholecystectomy & 3 & Alive (FUNR) \\
Galliative & Gastroenterostomy & 1 & Dead (9 months) \\
None & - & $1^{a}$ & Dead (day 4-liver failure) \\
Unknown & Unknown & 3 & Unknown \\
\hline
\end{tabular}

${ }^{a}$ Synchronous adenocarcinomas of duodenum and pancreas were present. FUNR, follow-up not reported.

(17). A correlation between adenocarcinomas (exclusive of carcinoids) of the small bowel in NF-1 patients was proposed by Jones (11), but has been disputed by Williams (34). Kingston (19) first proposed a relation between NF-1 and carcinomas of the periampullary region. In more recent years, Klein (17) suggested that the epithelial cell component of the above-mentioned endodermal-neuroectodermal complex may also be the origin of duodenal and pancreatic adenocarcinomas reported in patients with NF-1.

On the basis of these suggestions and of our findings, a predisposition of epithelial (either endocrine or exocrine) and nonepithelial tissues of the ampullary and periampullary region, resulting in a higher risk of tumor development, may be postulated in NF-1 patients.

From the therapeutic point of view, potentially curative surgery has been possible in a high number of the cases referred to in the literature (Table 2). In consideration of the greater risk of neoplastic degeneration also of the non-neoplastic tissue adjacent to the known ampullary or periampullary neoplasm, a widely demolitive surgical treatment (Whipple's procedure) would seem to be the surgery of choice. If only a local resection of the tumor is performed, it is appropriate to proceed to an extensive follow-up program of the periampullary area so as to permit early diagnosis of a possible second tumor and its surgical treatment.

The inadequacy of follow-up in the reported cases does not allow for a definitive judgment on the prognosis of adenocarcinomas in NF-1. However, it is noteworthy that three patients present a disease-free survival of 22 (13), 10 (19), and 3 years (present case).

In conclusion, the ampullary and periampullary adenocarcinomas in NF-1 patients have peculiar features, suggesting a widespread predisposition to cancer development in periampullary tissues and requiring widely demolitive surgery. Moreover, they occur at a younger age than those occurring in non-NF-1 patients, may be associated with additional periampullary epithelial tumors, are often operable and may present long survival.

\section{REFERENCES}

1. Barker D, Wright E, Nguyen K, Cannon L, Fain P, Goldgar D, et al. Gene for von Recklinghausen neurofibromatosis is in the pericentromeric region of chromosome 17. Science 1987; 236:1100-2.

2. Gasparini P, D’Agruma L, Pio de Cillis G, Balestrazzi P, Mingarelli R, Zelante L. Scanning, the first part of the neurofibromatosis type 1 gene by RNA-SSCP: identification of three novel mutations and of two novel polymorphisms. Hum Genet 1996;97:492-5.

3. Ottini L, Esposito DL, Richetta A, Carlesimo M, Palmirotta R, Verì MC, et al. Alterations of microsatellites in neurofibromas of von Recklinghausen's disease. Cancer Res 1995;55: 5677-80.

4. Robinson PN, Buske A, Neumann R, Tinshert S, Nurnberg P. Recurrent 2-bp deletion in exon 10c of the NF1 gene in two cases of von Recklinghausen's neurofibromatosis. Hum Mutat $1996 ; 7: 85-8$.

5. Rasmussen SA, Friedman JM. NF1 gene and neurofibromatosis 1. Am J Epidemol 2000;151:33-40.

6. Davis GB, Berk RN. Intestinal neurofibromas in Von Recklinghausen's disease. Am J Gastroenterol 1973;60:410-4.

7. Fuller CE, Williams GT. Gastrointestinal manifestations of type 1 neurofibromatosis (von Recklinghausen's disease). Histopathology 1991;19:1-11.

8. Designan G, Dunn GD, Halter S. Adenocarcinoma of the esophagus associated with neurofibromatosis. J Tenn Med Assoc 1985;78:138-40.

9. Basu S, Majumdar J, Mitra R, Chowdhury JR. Primary adenocarcinoma of the stomach associated with peripheral neurofibromatosis: report of a case. Surg Today 1997;27:57-9.

10. Wormsley KG, Logan WE, Sorrell VF, Cole GC. Neurofibromatosis with pancreatic duct obstruction and steatorrhea. Postgrad Med J 1967;43:432-5.

11. Jones TJ, Marshall TL. Neurofibromatosis and small bowel adenocarcinoma: an unrecognised association. Gut 1987;28: 1173-6.

12. Jenkins DH, Gill W. A case of carcinoma of the colon in association with neurofibromatosis. Br J Surg 1972;59:322-3.

13. Ching CK, Greer AJ. Metachronous biliary tract cancers in a patient with von Recklinghausen disease. Am J Gastroenterol 1993;88:1124-5.

14. Sprengers DP, Knockaert DC, Van Steenbergen W, Pennincks F. Primary bile duct carcinoma and von Recklinghausen's disease. Annu Intern Med 1987;106:772.

15. Komai K, Wada K, Sakata Y, Okawa M, Sasaki D, Yoshida Y, et al. Eosinophilia and hepatocellular carcinoma associated with von Recklinghausen's disease. Nippon Shokakibyo Gakkai Zasshi 1984;81:3019-22.

16. Keller R, Logan GM. Adenocarcinoma of the pancreas associated with neurofibromatosis. Cancer 1977;39:1264-6.

17. Klein A, Clemens J, Cameron J. Periampullary neoplasms in von Recklinghausen's disease. Surgery 1989;106:815-9. 
18. Colarian J, Pietruk T, LaFave L, Calzada R. Adenocarcinoma of the ampulla of Vater associated with neurofibromatosis. J Clin Gastroenterol 1990;12:118-9.

19. Kingston RD. Neurofibromatosis and small bowel adenocarcinoma-an unrecognised association. Gut 1988;29:134.

20. Paraf F, Poynard T, Bedossa P, Gayral F, Naveau S, Pignon JP, et al. Adenocarcinoma of the Vater's ampulla and von Recklinghausen's disease. Annu Intern Med 1987;107:785.

21. Knight WA, Murphy WK, Gottlieb JA. Neurofibromatosis associated with malignant neurofibromas. Arch Dermatol 1973;107:747-50.

22. Niv Y, Abu-Avid S, Oren M. Adenocarcinoma of pancreas and duodenum associated with cutaneous neurofibromatosis. Am J Med 1987;82:384-5.

23. Sorensen SA, Mubirhill JJ, Nielsen A. Long term follow-up of von Recklinghausen's neurofibromatosis: survival and malignant neoplasm. N Engl J Med 1986;314:1010-5.

24. McGlinchey JJ, Santer GJ, Haqqani MT. Primary carcinoma of the duodenum associated with cutaneous neurofibromatosis. Postgrad Med J 1982;58:115-6.

25. Martin FM, Rossi RL, Dorrucci V, Silverman ML, Braasch JW. Clinical and pathologic correlations in patients with periampullary tumors. Arch Surg 1990;125:723-6.

26. Schaldenbrand JD, Appleman HD. Solitary solid stromal gastrointestinal tumors in von Recklinghausen's disease with minimal smooth muscle differentiation. Hum Pathol 1984; 15:229-32.

27. Ishizaki Y, Tada Y, Ispida T, Bandai Y, Idezuki Y, Hitoshi N, et al. Leiomyosarcoma of the small intestine associated with von Recklinghausen's disease: report of a case. Surgery 1992; 111:706-10.

28. Alamowitch C, Larousse C. Association of Recklinghausen's disease with carcinoid of Vater's ampulla. A new nosologic entity: apudoma. A case. Nouv Presse Med 1982;11:3255-7.

29. Arnesjo B, Idvoll I, Ishe I, Telenivs M, Tylen U. Concomitant occurrence of neurofibromatosis and carcinoid of the intestine. Scand J Gastroenterol 1973;8:637-43.

30. Barber PV. Carcinoid tumor of the ampulla of Vater associated with cutaneous neurofibromatosis. Postgrad Med 1976; 52:514-7.

31. Johnson L, Weaver M. Von Recklinghausen's disease and gastrointestinal carcinoids. JAMA 1981;245:2496.

32. Dayal Y, Tallberg KA, Nummemacher G, De Lellis RA, Wolfe HJ. Duodenal carcinoids in patients with and without neurofibromatosis. Am J Surg Pathol 1986;10:348-57.

33. Perrone T. Duodenal gangliocytic paraganglioma and carcinoid. Am J Surg Pathol 1986;10:147-8.

34. Williams GT, Griffiths DFR, Williams ED. Small intestinal adenocarcinoma, duodenal carcinoid tumor, and von Recklinghausen's neurofibromatosis. Gut 1988;29:553. 